\title{
An Investigation of Corporate Image Effect on WOM: The Role of Customer Satisfaction and Trust
}

\author{
Methaq Ahmed Sallam ${ }^{1}$ \\ ${ }^{1}$ College of Administrative Sciences, Najran University, Najran, Saudi Arabia \\ Correspondence: Methaq Ahmed Sallam, College of Administrative Sciences, Najran University, P.O. Box 1988, \\ Najran 11001, Saudi Arabia.
}

Received: March 17, 2016

Accepted: March 29, 2016

Online Published: April 22, 2016

doi:10.5430/ijba.v7n3p27

URL: http://dx.doi.org/10.5430/ijba.v7n3p27

\begin{abstract}
The use of positive corporate image by companies continues to be a popular method to support the customer satisfaction, and to encourage his/her trust on the company, and lead the customer to own more positive word of mouth about the company and its brand. When the customers have the positive corporate image they focus on aspects of a company, in addition, they usually express it by using the positive words of mouth, and which in turn is considered the goal of any company. The reason that lies behind using corporate image is its direct and indirect strong impacts that build customer satisfaction and makes customers more trust to speak positively about the company. This theoretical paper develops a conceptual framework that explains how independent variable (corporate image) effects on dependent variable which is called word of mouth when trust and customer satisfaction are mediating. A study carried out in Saudi Arabia using 150 respondents as consumers who used any kinds of car service. Path analysis confirmed that, corporate image had positive impact on customers' satisfaction and trust. In addition, the study illustrated that customer's trust had greater positive impact on customer's word of mouth than customer's satisfaction.
\end{abstract}

Keywords: corporate image, trust, customer satisfaction, WOM

\section{Introduction}

Word-of-mouth communication simply involves people sharing their assessment of their experiences. Word-of-mouth communication, which relates both to positive and negative evaluations of service encounters, has been shown to influence other people's purchase behavior (NG, 2001). Lo Chung (2012) Mentioned that word of mouth deals with the process of transferring of information from one person to the other through oral communication. The concept of word of mouth has become an important term in the marketing activities conducted by various organizations. Interpersonal communication or the word of mouth has gained importance in the decision making of the consumers. Word of mouth is gaining importance among the societal changes observed in the environment and has become one of the most important and effective communication channel.

A positive corporate image is not only increasing competition but also encourage consumers to repurchase (Tu et al, 2013). Corporate image helps consumers obtain a better understanding of the products offered by specific corporations and further mitigate their uncertainty while making buying decisions (Lin and lu, 2010), and they mentioned that corporate image plays important role to enhance the trust of customer.(Tu et al, 2013) illustrated that corporate image form positive customer satisfaction, In addition, (Sichtmann, 2007) and (NG, 2001) explored that trust and customer satisfaction encourage the customer WOM.

\subsection{Problem Statement}

Although many studies have been conducted on this issue, but there are still gaps that need to be filled in the literature. Studies conducted by previous researchers only focused on certain aspects of customer's WOM process, and the variables used in those studies were segmented in natural in previous studies. In other words, the model proposed in this study is an integrative one, and come from four separate models found in the area related literature, e.g. study of ( $\mathrm{Tu}$ et al, 2013) explored the relationship between corporate image and customer satisfaction, study of (Lin and lu, 2010) explored the relationship between corporate image and trust, study of (Sichtmann, 2007) explored the effect of trust on WOM, while study of $(\mathrm{NG}, 2001)$ illustrated the effect of customer satisfaction on WOM. This 
means, that four main models of this study were segmented in four different studies, and each one was separated alone, and this study tries to integrate them in one conceptual framework, and this is the contribution of this study, another contribution, this study carried out in developing country.

\section{Literature Review}

One of the most essential topics in marketing management is the subject WOM. (Rust, 1996) mentioned that word-of-mouth recommendations from friends, family, and colleagues who are satisfied with a company have a measurable impact on sales. (Struebing, 1996) mentioned that a new academic study shows that revenue streams can be generated from attracting new customers via word-of-mouth recommendations, increasing the percentage of retained customers, and increasing spending or usage by existing customers.In addition, corporate image plays an important role to form customer satisfaction and trust, therefore, customer satisfaction and trust lead to support WOM. This conceptual paper try to explore how independent variable which called is corporate image impacts on dependent variable which is called WOM when customer satisfaction and trust are mediating, and these issues are discussed in details to allay concepts of these concerns here.

\subsection{Corporate Image}

Dowling (1986) defined image as specific viewpoints towards a certain matter through description, memory, or other ways of association with such matter. It results from the interactions among people's impression, existing beliefs, thoughts, and feelings on such a thing. (Giovanis et al., 2014) mentioned that corporate image has been identified as an important factor in the overall judgment of a service provider. It is defined as the mental picture that springs up at the mention of a firm's name. It is a composite psychological impression that continuously changes with the firm's circumstances, media coverage, performance, etc. Similar to a firm's reputation or goodwill, it is the public perception of the firm, rather than a reflection of its actual state or position. MacInnis and Price (1987) pointed out that corporate image results from an evaluation process, which originates from thoughts, feelings, and previous consumption experience in relation to a business entity, turning consumers' memories into spiritual impression (Yuille and Catchpole, 1977). (Gray, 1986) suggested that corporate image is the combination of consumers' perception and attitude towards a business entity.

Robertson and Gatignon (1986) further proposed that corporate image helps facilitate consumers' knowledge on products or services offered by a certain company and reduces uncertainty while making buying decisions. Consumers are directed to buy commodities from a company with good corporate image to reduce their risks. (Nguyen and Leblanc, 2001) found that corporate image is associated with a company's constitution and nature of behavior. For example, corporate name, corporate building, and product or service quality may reinforce customer's' impression on a company.

Corporate image is defined as the "overall impression" left in the customers' mind as a result of accumulative feelings, ideas, attitudes and experiences with the organization, stored in memory, transformed into a positive/negative meaning, retrieved to reconstruct image and recalled when the name of the organization is heard or brought to ones' mind (Dowling, 1986).

Thus, corporate image is a result of communication process in which the organizations create and spread a specific message that constitutes their strategic intent; mission, vision, goals and identity that reflects their core values that they cherish (Leuthesser and Kohli, 1997).

Walters and Paul (1970) indicated that corporate image features four aspects: subjectivity, screening, elaboration, and changeability. (Walters, 1978) suggested that the subjective attitude, feelings, or impression on an enterprise or its activities held by consumers are connected with attitude.

\subsection{Customer Satisfaction}

The word "satisfaction" is significant by itself; as psychologists debate our overall "life" satisfaction so management seeks to provide job satisfaction and consumer satisfaction. Consumers demand satisfaction. Consumer behavior researchers seek to understand and explain consumer satisfaction (Wan, 2007). According to (Oliver, 1997) satisfaction is defined from the mixture of both affection (emotion) and cognition approach as "the consumer's fulfillment response. (Almossawi, 2012) said that many previous studies has been extensively focused on customer's satisfaction e.g. (Oliver, 1980). (Kotler and Keller, 2008) define satisfaction as "a person's feeling of pleasure or disappointment resulting from comparing a product's perceived performance (or outcome) in relation to his/her expectations". This definition is supported by many other studies, for example, (Oliver, 1980). Others define customer satisfaction as the feeling or attitude of customers toward a product/service after it has been used (Hansemark \& Albinsson, 2004). 
Parasuraman et al., (1988) Customer satisfaction has emerged as one of the most powerful tools for sustaining a competitive advantage for business success and survival nowadays. Joewono and Kubota (2007) indicated that customer satisfaction was from the product and service evaluations according to the customer experiences as well as the overall measurement on the consuming experience.

York et al., (2009) mentioned that customer satisfaction's importance, specifically service encounters, is well documented in the marketing and management literature, it is recognized as an important goal largely because empirical studies establish a relationship between customer satisfaction, customer loyalty and long-term profitability. Specifically, during the past two decades, research centered around exploring customer satisfaction's impact on customer retention and loyalty, branding, profits, market share and growth (Ammar et al., 2008). Therefore, it is not surprising that organizations spend substantial resources measuring and managing customer satisfaction (Hasin, 2001; Lee; 2005).

Aburoub et al., (2011) mentioned that customers satisfaction in the first place in interested in defining of buying behavior. The research stressed the customer's satisfaction role in focusing on expectation, performance achieved, and satisfaction. Comparison between expectation and performance achieved leads either to customers satisfaction or dissatisfaction of customer.

\subsection{Trust}

Trust has been defined as consumers' willingness to rely upon their expectations about a firm's future behavior (Walshetet al., 2010). Trust is an essential issue in human relationships. Morgan and Hunt (1994) pointed out that trust means someone regards his/her transactional partners as reliable and honest and has confidence in them. (Morgan and Hunt, 1994) referred that trust is an essential issue in human relationships, they pointed out that trust means someone regards his/her transactional partners as reliable and honest and has confidence in them.

Smith and Barclay (1997) suggested that trust is a cognitive expectation or emotional viewpoint. It is also a behavior bearing risks or willingness to be engaged in the above said behavior. If the object trusted is an organization, trust is defined as the customers' dependence on service quality and reliability offered by that organization (Garbarino and Johnson, 1999). Trust is a very important factor in today's business competitive environment. Trust in a business relationship helps reduce business risks (Anderson, 1998). Smeltzer (1997) pointed out that mutual trust is influenced by psychological identification, image, and reputation perceived between suppliers and buyers.

Singh and Sirdeshmukh (2000) considered the definition of trust came before and after transactions. The trust presented before the transactions directly influenced satisfaction after transactions, while the trust shown after transactions directly influenced trust afterwards.

\subsection{Word of Mouth (WOM)}

Money (2004) mentioned that consumers search for information prior to making a purchase in order to reduce perceived risk. One such source of information is word of mouth (WOM). Marketing researchers have shown that WOM communication has an impact on consumer attitudes, consumer risk taking, short-term and long-term product judgments and purchase decisions and choice behavior. Kemp (2011) informed that decades of consumer research has shown Word-of-Mouth Communication (WOMC) to be a powerful influence on consumers' brand attitudes, judgments, and purchase intentions.

Word-of-mouth means the measure of consumers' major informal communication. In early times, word-of-mouth meant at least two consumers, without commercial intention, communicating face-to-face regarding brands, products, or services. Communication is critical in customers' consumption and the process is called word-of-mouth (Lin \& Chen, 2005). Word-of-mouth (WOM) communication usually invites thoughts on others. Some people engage in WOM communication to seek other people's opinions on products or companies. Other people first consider the characteristics of potential WOM message receivers and then deliver WOM messages to the relevant receiver (Allsop, Bassett \& Hoskins, 2007).

Word of mouth is gaining importance among the societal changes observed in the environment and has become one of the most important and effective communication channel. (Harrison-Walker, 2001) defined WOM as "informal, person-to-person communication between a perceived non-commercial communicator and a receiver regarding a brand, a product, an organization or a service. The basic idea behind WOM is that information about products, services, stores, companies and so on can spread from one consumer to another. In its broadest sense, WOM communication includes any information about a target object (e.g. company, brand) transferred from one individual to another either in person or via some communication medium (Brown et al., 2005). WOM is described as the process that allows consumers to share information and opinions that direct buyers toward and away from specific 
products, brands and services (Hawkins et al., 2004). There is recent focus on WOM in the literature on relationship marketing as a potential response that can emerge from efforts directed at forming relationships with consumers (e.g. Verhoef et al., 2002).

Lias et al., (2012) mentioned that word of mouth has been an age old concept where a person shares his view with another person. The views of the person can be related to a product or the service he have received. The studies in consumer behavior suggest that words of mouth have a strong influence on the psychology of the person. The influence of word of mouth can have both positive and negative aspects. Relating word of mouth to the consumer behavior, it can be interpreted that the positive word of mouth increases the likelihood of the consumers in opting for the product, whereas the negative word of mouth does the reverse. The overall effect of the word of mouth is dependent on two factors. The total number of people being exposed to positive word of mouth or negative word of mouth helps in judging the final influence.

\subsection{The Relationship between Corporate Image and Customer Satisfaction}

Cameran et al., (2010) mentioned that there is considerable evidence in the literature supporting the relationship between a company's image and the level of satisfaction reported by its customers, for this reason, it is often argued that customer satisfaction should be the ultimate goal of all firms. Many previous studies explored the relationship between corporate image and customer satisfaction, e.g. (Abd-El-Salam \& Shawky, 2013) explored that corporate image had positive impact on customer satisfaction. (Cameran et al., 2008) found that corporate image had strong effect impact on customer satisfaction. Cameran et al., (2010) explored that corporate image had strong relationship and significant effect on customer satisfaction.

\subsection{The Relationship between Corporate Image and Trust}

When the consumer owns a good image about the company, the company's image - via the time - in turn affect his trust.Previous literature mainly focused on the influences of corporate image on consumers' truste.g. (Grewal et al., 1998; Solomon, 1999), while few studies have discussed the influence of corporate image on consumers' trust. Few previous studies explored the relationship between corporate image and customer trust, e.g. (Lin and Lu, 2010) found that corporate image had strong effect on trust.

\subsection{The Relationship between Customer Satisfaction and WOM}

Positive customer's WOM often come from his/her satisfaction about the company. Previous literature mainly focused on the influences of customer's satisfaction on consumers' WOM e.g. (NC, 2001) found that customer satisfaction effects of customer's word of mouth. Aljumaa et al., (2014) explored that customer satisfaction has strong effect on customer's word of mouth. In addition, (Jayasankaraprasadet al., 2012) found that customer's satisfaction effects on his/her word of mouth. Ranaweera et al., (2003) found that there is strong relationship between these two variables, and explored that customer's satisfaction effects positively on customer's word of mouth.

\subsection{The Relationship between Trust and WOM}

It is known, that the consumer who has trust on a company, he speaks a positive manner about the company and its products. Few previous studies explored the strong relationship between customer's trust and word of mouth, e.g. (Sichtmann, 2007) illustrated that trust had strong impacts on customer's word of mouth. In addition, Ranaweera et al., (2003) found that customer's trust effects on word of mouth. (Salehnia et al., 2014) explored that customer's trust effect positively on customer's word of mouth.

\section{The Proposed Conceptual Framework}

The conceptual framework below is proposed to ensure that corporate image is as independent variable impacts on dependent variable which is called customer's word of mouth when customer satisfaction and trust are mediating.

Based on what have been presented in the literature, the following framework (Figure 1) and four hypotheses have been developed for the study. 


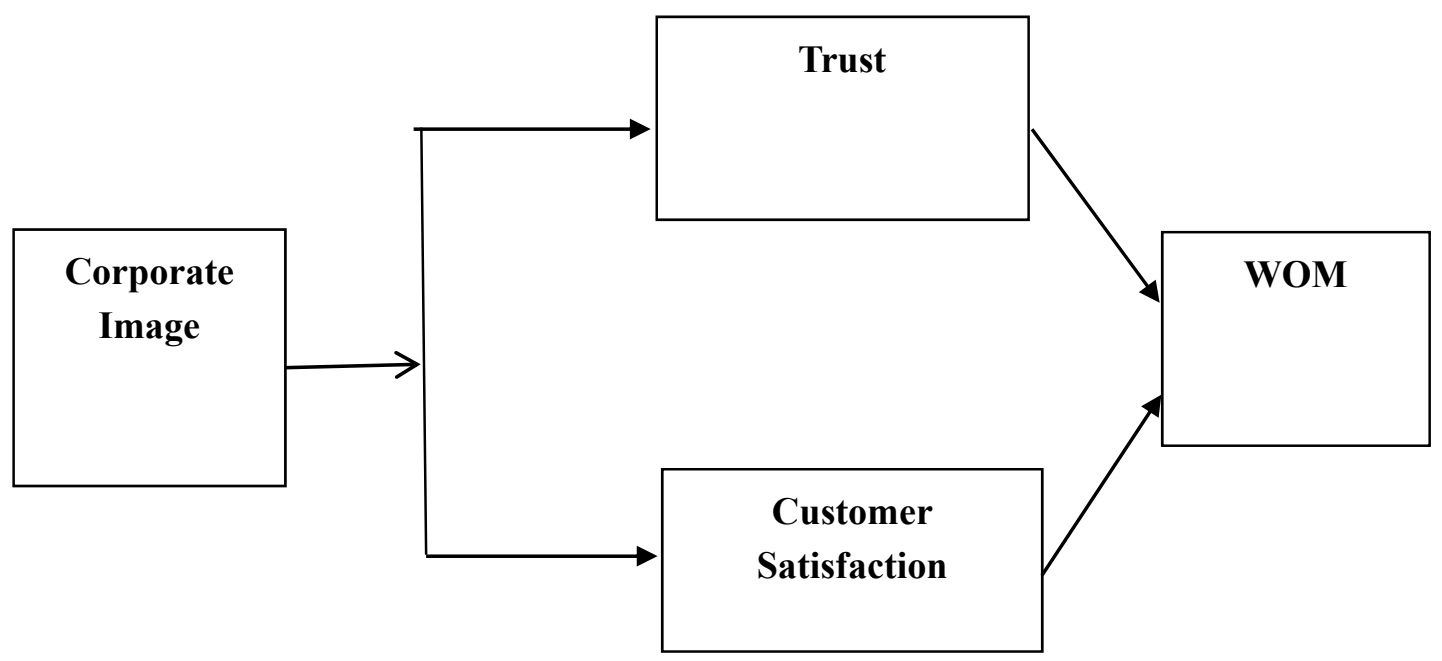

Figure. 1. Proposed conceptual framework

H1. Corporate image has positive effect on customer satisfaction.

H2. Corporate image has positive effect on customer trust.

H3. Customer satisfaction has positive impact on customer word of mouth.

H3. Customer trust has positive impact on customer word of mouth.

\section{Research Methodology}

\subsection{Sampling}

Based on the Sekaran (2008) sampling refers to the procedures of choosing a enough mount of elements from existing population, so that a research of the sample and a finding of its properties or features would make it possible to generalize such properties or features to the population elements. Young and middle age people who are living in Najran city and using any kinds of cars services are a targeted group to fulfill the instrument of this study. Most of these students have at least three-year experience to deal with cars services. The samples for this study are randomly chosen among the targeted population. The total of 180 questionnaires were distributed to participants, of which 30 questionnaires were incomplete or there were missing data that could not be analyzed. So, a total of 150 questionnaires were analyzed and the findings are presented in the next part.

\subsection{Variable Measurement}

A five-point Likert scale ranging from $1=$ strongly disagree to $5=$ strongly agree were used to measure responses for all corporate image, customer trust, customer satisfaction and customer's word of mouth variables in the study. This study tried to adopt measurements from previous studies as shown here, and in the same time tried to adapt them to be suitable with this study. For example, items to measure corporate image were adopted from Aydin et al., (2004) studies. Three Items to measure satisfaction were adopted from Moshe, (2003) study and four items were adopted from (Long et al., 2009). For customer's word of mouth, three items were adopted from the study of Sweeney and Swait (2000).

\section{Results}

\subsection{Respondents' Background}

Respondents' Background Of the total 150 respondents surveyed, most were not married (27.4\%), while (72.6\%) not married, and were in the age between 20-30 years (66.1\%), and were in the age between $31-40$ years (33.1\%) while $(2.8 \%)$ were in the age over 40 years.

\subsection{Simple Regression Analysis}

The simple regression analysis is the statistical technique used to analyze the relationship between a single dependent (criterion) variable and single independent (predictor) variables. 
Corporate image has been hypothesized in $\mathrm{H} 1$ to have an effect on customer's satisfaction. Table 1 illustrates that Corporate image explained (0.24) of the variance in customer's satisfaction $\left(\mathrm{R}^{2}=0.24\right)$. The variable of Corporate image was found to be positively and significantly associated with customer's satisfaction as $(\beta=0.47, p<.01)$. It is obvious then that $\mathrm{H} 1$ which has proposed the effect of Corporate image on customer's satisfaction is accepted. This finding seems to be in line with the previous study of Cameran et al. (2008).

Table 1. Simple Regression Analyses: Relationship between corporate image and customer's satisfaction

\begin{tabular}{llllll}
\hline $\begin{array}{l}\text { Customer Satisfaction } \\
\text { Path } c\end{array}$ & Beta & t-test & Sig & VIF & tolerance \\
\hline Corporate Image & & & & & \\
\hline $\mathrm{R}^{2}$ & $.47^{* *}$ & 6.5 & .000 & 1.000 & 1.000 \\
Adjusted R Square & .24 & & & & \\
F Value & .24 & & & & \\
\hline
\end{tabular}

\subsection{Multiple Regression Analysis}

The multiple regression analysis is the statistical technique used to analyze the relationship between a single dependent (criterion) variable and several independent (predictor) variables (Hair et al., 1998; 2000). In order to test the hypothesis, both variables customer satisfaction and customer trust seem to have an effect on customer's loyalty with a significant value of $\beta=0.18(\mathrm{p}>0.01)$ and $\beta=0.37(\mathrm{p}>0.05)$ sequential. These results indicate that $\mathrm{H} 3$ and $\mathrm{H} 4$ are accepted and Table 2 bellow shows that.

Table 2. Multiple Regression Analyses: The relationship between customer's satisfaction and trust with customer's WOM

\begin{tabular}{llllll}
\hline Customer's WOM & Beta & t-test & Sig & VIF & tolerance \\
\hline Customer Satisfaction & $.18^{*}$ & 1.4 .000 & 2.1 .469 & \\
\cline { 2 - 5 } Trust & $.37^{* *}$ & 3.87 .000 & 2.1 .469 & \\
\hline $\mathrm{R}^{2}$ & .168 & & & & \\
Adjusted R Square & .159 & & & & \\
F Value & $18.6^{* *}$ & & & & \\
\hline
\end{tabular}

\section{Discussion and Implications}

The objective of this study as stated earlier is to investigate the corporate image relationship with customer satisfaction and customer trust, the effect of customer satisfaction and customer trust on customer's word of mouth, and to illustrate the mediating role of customer satisfaction and customer trust between corporate image and customer's word of mouth. The study found that corporate image was found to have a positive impact on customer's satisfaction. In addition, the study explored that customer's trust has greater significant effect on customer's word of mouth, than customer's satisfaction. The study's results illustrated that both mediating of the study e.g. (customer's satisfaction and trust) are partial mediating.

\section{Conclusions}

This study has undertaken an in-depth review of corporate image and its effect on customer's satisfaction and customer's trust, and beside that it explored the effect of customer's satisfaction and customer's trust on customer's word of mouth. The results show that corporate image has positive effect on customer satisfaction and customer trust, and It concluded that customer's trust has greater significant on customer's word of mouth rather than customer's trust. The findings explore an understanding of Saudi's consumer behavior and thus gave practitioners some ideas in understanding how to use the corporate image variable to enhance the consumers' satisfaction and customer' trust. in addition, the study's results explored that customer's trust had greater effect on customer's word of mouth than customer's satisfaction, and this results help policy makers of companies to use customer's trust well and to improve 
the role of customer's satisfaction in future. However, the limitations of the study need to be noted. For instance, using a sample size of only 150 consumers means that the results cannot be generalized for all Saudi consumers. And that collecting data at only one point in time knowing that corporate image is based on long-term marketing strategies that needs time to be built and to be nurtured points to the more appropriately used longitudinal approach study in order to cope with the long-time nature of the marketing strategies investigated in this study.

This study was the first in Saudi Arabia context that examine the effect of corporate image on customer's word-of-mouth when customer's satisfaction and customer's trust are mediating.

\section{Recommendation}

Based on to what mentioned above, it can be argued that the corporate image Influence on bout customer's satisfaction and trust. In addition, the customers' trust had greater effect on customer's word of mouth than customer's satisfaction. Companies in Saudi Arabia should pay more attention to create strong image of their companies, to build customers' trust and satisfaction with their services, this is due to the fact that customers trust and satisfaction would impact greatly on word of mouth, which is considered to be one of the cheapest and easiest way of attracting new customers instead of spending a lot of money of TV ads, billboards, etc. This study will help the companies' managers in sector of car services especially the marketing managers to understand the market orientations in their decision making process and also help them to use those variables well to create more satisfied customers with the provided services.

\section{Limitation and Future Research}

It is hoped that the study can provide insights for further research in this area and help policy makers of companies to employ the implementation of the role of corporate image as a main driver of consumer's satisfaction and trust, which are lead to enhance customer's word of mouth behavior in marketing. However, the limitations of the study need to be noted. For instance, using a sample size of only 150 consumers means that the results cannot be generalized for all Saudi consumers. And that collecting data at only one point in time knowing that corporate image is based on long-term marketing strategies that needs time to be built and to be nurtured points to the more appropriately used longitudinal approach study in order to cope with the long-time nature of the marketing strategies investigated in this study. In addition, The same research needs to be conducted in other service industries that have long-term relationship with their customers such as banking industries.Lastly, like any other studies, this study has its own limitation; one of which is the conduct of this study a developing country that people did not understand the significance of this study and required times to explain the process, some of which were worthless.

\section{References}

Abd-El-Salam, E., \& Shawky, A. (2013, January). The impact of corporate image and reputation on service quality, customer satisfaction and customer loyalty: testing the mediating role. Case analysis in an international service company. The Business \& Management Review, 3(2).

Aburoub, A., Hersh, A., \& Aladwan, K. (2011). Relationship between Internal Marketing and Service Quality with Customers' Satisfaction. International Journal of Marketing Studies, 3(2), 107.

Allahham, A., \& Aljumaa, A. (2014). Analyzing Antecedents of Customer Satisfaction and its Impact on Word Of Mouth Communication in LifeInsurance Services. International Journal of Management Sciences and Business Research, 3(4).

Allsop, T., Bassett, R., \& Hoskins, J. (2007, Dec.). Word-of-Mouth Research: Principles and Applications. Journal of Advertising Research, 47(4), 398. http://dx.doi.org/10.2501/S0021849907070419

Almossawi, M. (2012). Customer Satisfaction in the Mobile Telecom Industry in Bahrain: Antecedents and Consequences. International Journal of Marketing Studies, 4(6). http://dx.doi.org/10.5539/ijms.v4n6p139

Ammar, S., Moore, D., \& Wright, R. (2008). Analysing customer satisfaction surveys using a fuzzy rule-based decision support system: enhancing customer relationship management. Journal of Database Marketing and Customer Strategy Management, 15(2), 91-105. http://dx.doi.org/10.1057/dbm.2008.2

Anderson, E. W. (1998). Customer satisfaction and word-of-mouth. Journal of Service Research, 1(1), 1-14.

Brown, T. J., Barry, T. E., Dacin, P. A., \& Gunst, R. F. (2005). Spreading the word: investigating antecedents ofconsumer's positive word-of-mouth intentions and behaviors in a retailing context. Journal of the Academy of Marketing Science, 33(2), 123-138. http://dx.doi.org/10.1177/0092070304268417

Cameran, M., Moizer, P., \& Pettinicchio, A. (2010, March). Customer satisfaction, corporate image, and service qualityin professional services. The Service Industries Journal, 30(3), 421-435. 
Dowling, G. R. (1986). Managing your corporate image. Industrial Marketing Management, 15, 109-15.

Garbarino, E., \& Johnson, M. (1999). The different roles of satisfaction, trust and commitmentfor relational and transactional consumers. Journal of Marketing, 63(2), 70-87. http://dx.doi.org/10.2307/1251946

Giovanis, A., Zondiros, D., \& Tomaras, P. (2014). The antecedents of customer loyalty for broadband services: Therole of service quality, emotional satisfaction and corporate image. In Apostolos N. Giovanis et al. (Eds.), Procedia - Social and Behavioral Sciences (Vol. 148, pp. 236-244). http://dx.doi.org/10.1016/j.sbspro.2014.07.039

Gray, G. (1986). Interaction of learner control and prior understanding in computer-assisted video instruction. Journal of Educational Psychology, 78(3), 325-7.

Grewal, D., Monroe, K. B., \& Krishnan, R. (1998). 'The effects of price-comparison advertising onbuyers' perceptions of acquisition value, transaction value, and behavioral intentions. Journal ofMarketing, 62(2), 46-59. http://dx.doi.org/10.2307/1252160

Hansemark, O. C., \& Albinsson, M. (2004). Customer Satisfaction and Retention: The Experiences of Individual Employees. Managing Service Quality, 14(1), 40-57. http://dx.doi.org/10.1108/09604520410513668

Harrison, W. L. J. (2001). The measurement of word-of-mouth communication and investigation of servicequality and customer commitment as potential antecedents. Journal of Service Research, 4(1), 60-75.

Hasin, M. (2001). Statistical measures of customer satisfaction for healthcare quality assurance: a case study. International Journal of Health Care Quality Assurance, 14(1), 6-13.

Hawkins, D. I., Best, R., \& Coney, K. A. (2004). Consumer Behavior: Building Marketing Strategy (9th ed.). Boston, MA: McGraw-Hill.

Hennig-Thurau, T., Gwinner, K. P., Walsh, G., \& Gremler, D. D. (2004). Electronic word-of-mouth via consumer-opinion platform: what motivates consumers to articulate themselves onthe internet?. Journal of Interactive Marketing, 18, 38-52. http://dx.doi.org/10.1002/dir.10073

Jayasankaraprasad, C., \& Vijaya Kumar, L. (2012, December). Antecedents and Consequences of Customer Satisfaction in Food \& Grocery Retailing: An Empirical Analysis. Decision, 39(3).

Joewono, T. B., \& Kubota, H. (2005). The Characteristics of Paratransit and Non-Motorized Transport in Bandung, Indonesia. Journal of 6th EASTS (Eastern Asia Society for Transportation Studies) Conference. Bangkok, Thailand. September 21-24. 2005a.

Kemp, E., \& Bui, M. (2011). Healthy brands: establishing brand credibility, commitment and connection among consumers. Journal of Consumer Marketing, 28(6), 429-437. http://dx.doi.org/10.1108/07363761111165949

Kotler, P., \& Keller, K. L. (2008). Marketing Management. Pearson Prentice Hall.

Leuthesser, L., Kohli, C. S., \& Harich, K. R. (1995). 'Brand equity: the halo effect measure. European Journal of Marketing, 29(4), 57-66. http://dx.doi.org/10.1108/03090569510086657

Liao, S. H., Chung, Y. C., Hung, Y. R., \& Widowati, R. (2010). The impacts of brand trust, customersatisfaction, and brand loyalty on word-of-mouth. Paper presented at the Industrial Engineering and EngineeringManagement (IEEM), 2010 IEEE International Conference.

Lin, L., \& Lu, C. (2010). The influence of corporate image,relationship marketing, and trust onpurchase intention: the moderatingeffects of word-of-mouth. Tourism Review, 65(3).

Lin, L.-Y., \& Chen, Y.-F. (2005). The effects of price promotion, perceived value and store image onconsumers' purchase intention: a case of $3 \mathrm{C}$ chain home appliances in Taipei area. Journal ofManagement and Information, $10,51-85$.

Long, Y., \& Ching, Y. (2009). The influence of corporate image, relationship marketing, and trust onpurchase intention: the moderatingeffects of word-of-mouth. Emerald Group Publishing Limited. http://dx.doi.org/10.1108/16605371011083503

MacInnis, D. J., \& Price, L. L. (1987). The role of imagery in information processing: review and extensions. Journal of Consumer Research, 13, 473-91. http://dx.doi.org/10.1086/209082

Money, R. B. (2004). Word-of-mouth promotion and switching behavior in Japanese and American business-to-business service clients. Journal of Business Research, 57, 297-305. 
Morgan, R. M., \& Hunt, S. D. (1994). The commitment-trust theory of relationship marketing. Journalof Marketing, 58(3), 20-38. http://dx.doi.org/10.2307/1252308

NC, Y. (2001). A Study of Customer Satisfaction, Return Intention, and Ward of Mouth Endorsement in University Dining Facilities. Submitted to the Faculty of theGraduate College of the Oklahoma State Universityin partial fulfillment of the requirements forthe Degree of MASTER OF SCIENCE, July, 2005.

Nguyen, N., \& Leblanc, G. (2001). Corporate image and corporate reputation in customers' retention decisions in services. Journal of Retailing and Consumer Services, $8,36$. http://dx.doi.org/10.1016/S0969-6989(00)00029-1

Oliver, R. L. (1980, November). A Cognitive Model of the Antecedents and Consequence of Satisfaction Decisions. Journal of Marketing Research, 17, 460-469. http://dx.doi.org/10.2307/3150499

Oliver, R. L. (1997). Satisfaction: A behavioural perspective on the consumer. New York, NY: McGraw-Hill.

Oliver, R. L. (1999). Whence Consumer Loyalty?. Journal of Marketing, 63, Special Issue, 33-44.

Oliver, R. L., \& Swan, J. E. (1989). Equity and disconfirmation perceptions as influences on merchant and product satisfaction. Journal of Consumer Research, 15, 372-383. http://dx.doi.org/10.1086/209223

Parasuraman, A., Zeithaml, V. A., \& Berry, L. L. (1988). SEVQUAL: A multiple-itemscale for measuring consumer perceptions of service quality. Journal of Retailing, 64(1), 12-40.

Ranaweera, C., \& Prabhu, J. (2003, Sep.). On the relative importance of customer satisfaction and trust as determinants of customer retention and positive word of mouth. Journal of Targeting, Measurement and Analysis for Marketing, 12(1), 82-90. http://dx.doi.org/10.1057/palgrave.jt.5740100

Robertson, T. S., \& Gatignon, H. (1986). Competitive effects on technology diffusion. Journal of Marketing, 50(3), 1-12. http://dx.doi.org/10.2307/1251581

Salehnia, N., Saki, M., Eshaghi, A., \& Salehnia, N. (2014). A Model of E-Loyalty and Word-Of-Mouth based on e-trust in E-banking services (Case Study: Mellat Bank). New Marketing Research Journal, Special Issue, 101-114. http://dx.doi.org/10.1109/ecdc.2014.6836764

Sherman, E., Mathur, A., \& Smith, R. B. (1997). Store Environment and Consumer PurchaseBehavior: Mediating Role of Consumer Emotions. Psychology and Marketing, 14(4), 361-378.

Sichtmann, C. (2007). An analysis of antecedents andconsequences of trust in acorporate brand. European Journal of Marketing, 41(9/10), 999-1015. http://dx.doi.org/10.1108/03090560710773318

Singh, J., \& Sirdeshmukh, D. (2000). Agency and trust mechanism in consumer satisfactionand loyalty judgements. Journal of the Academy of Marketing Science, 28(1), 150-67. http://dx.doi.org/10.1177/0092070300281014

Smeltzer, L. R. (1997). The meaning and origin of trust in buyer-supplier relationships. International Journal of Purchasing and Materials Management, 33(1), 40-8. http://dx.doi.org/10.1111/j.1745-493X.1997.tb00024.x

Solomon, M. (1999). Consumer Behavior: Buying, Having, and Being. Prentice-Hall, Englewood Cliffs, NJ.

Struebing, L. (1996). Word-of-mouth recommendations promote service quality. Quality Progress, 29(10), 18.

Tu, Y., Li, M., \& Chih, H. (2013, July). An Empirical Study of Corporate Brand Image, Customer Perceived Value and Satisfaction on Loyalty in Shoe Industry. Journal of Economics and Behavioral Studies, 5(7), 469-483.

Verhoef, P. C., Franses, P., \& Hoekstra, J. C. (2002). The effect of relational constructs on customer referrals and number of services purchased from a multiservice provider: does age of relationship matter? Journal of Academy of Marketing Science, 30(3), 202-12. http://dx.doi.org/10.1177/0092070302303002

Walsh, G., \& Vincent-Wayne, M. (2010). The effect of consumer confusion proneness on word of mouth, trust, and customer satisfaction. European Journal of Marketing, 44(6), 838-859.

Walters, C. G. (1978). Consumer Behavior: An Integrated Framework. Richard D. Irwin, New York, NY.

Walters, C. G., \& Paul, G. W. (1970). Consumer Behavior: An Intergated Frame Work. Richard D. Irwin, New York, NY.

York, A., \& McCarthy, K. (2009). Patient, staff and physician satisfaction: a new model, instrument and their implications. International Journal of Health Care Quality Assurance, 24(2), 2011 178-191.

Yuille, J. C., \& Catchpole, M. J. (1977). The role of imagery in models of cognition. Journal of Mental Imagery, 1, $171-80$. 